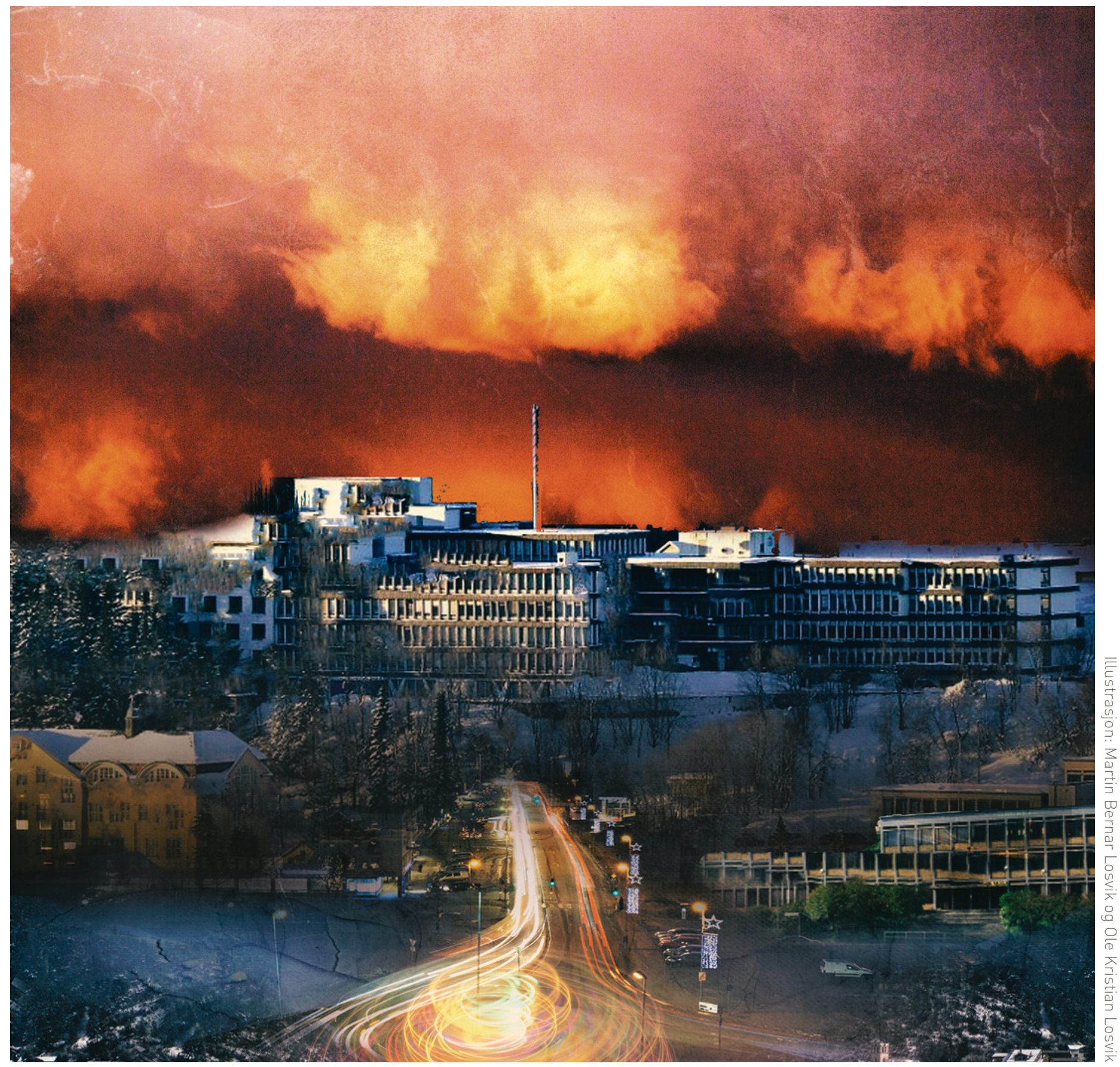

\title{
Universitetssykehuset Nord-Norge Narvik
}

(2) Forløperen til sykehuset i Narvik sto ferdig i 1905. Det var på den tiden ikke ansatt leger, men byens leger kunne legge inn pasienten og selv stå for behandlingen. Operasjonsstue kunne man leie for 50 øre per gang. Etter dette er det bygd på i flere omganger frem til dagens bygningsmasse sto ferdig. Narvik sykehus er i dag en del av Universitetssykehuset Nord-Norge.

Senger: 83 Ansatte: 559 